\section{The antimicrobial efficiency of green seaweeds from the Mediterranean coast against some pathogenic bacteria}

\section{ABSTRACT}

During the past several years, microbial resistance to common antibiotics has continually increased, and this growing resistance threatens the effective treatment of bacterial infections. Thus, there is increased research on novel Antimicrobial agents like seaweeds. In this study, crude extracts of three seaweeds (Ulva clathrate, Ulva lactuca and Ulva compressa) were obtained with a Soxhlet extraction apparatus. Evaluation of antimicrobial efficiency was carried out using well diffusion method and microdilution method (MIC) at different concentrations $(100-0.195 \mathrm{mg} / \mathrm{ml}$ ) for Staphylococcus aureus and Escherichia coli. The green seaweed extracts produced inhibition zones ranging from 7 to $12.5 \mathrm{~mm}$. Methanol extracts produced the strongest inhibitory activity against the tested bacterial species. Overall, this study provides data on the potential use of algal extracts for the development of antimicrobial agents to treat infectious diseases.

Keywords: Antimicrobial, green seaweeds, well diffusion method, microdilution method (MIC).

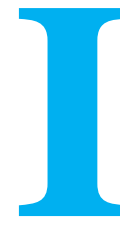

\section{NTRODUCTION}

Diseases affecting livestock can have a significant effect on animal productivity and production and human health (Das et al., 2019). The increasing spread of antibiotic resistance created serious problems for treatment of bacterial infections and continue to be a major challenge for public health worldwide (Elmanama et al., 2019). Infectious poultry shows an assortment of manifestations such as diarrhea, paralysis, and respiratory issues. It ought to be accentuated at the start that the counteraction of infection in a poultry rush through sound administration is vital (Das et al., 2019). This is because albeit some irresistible illnesses can be dealt with, for some it is an exercise in futility since cash and infectious fowls ought to be discarded immediately. Explicit medications are normally suggested for resistant microorgansims that might be partitioned into three classes: bacterial, protozoan, and fungal infections, while some popular illnesses can be forestalled by immunization (Logue et al., 2020). Damage to the intestinal quality due to pathogenic microbes may cause an issue in feed proficiency and diminished pace of gain to raise the absolute creation costs. Nevertheless, further extreme enteric harmed by bacterial diseases will cause plain sickness and high mortality in poultry rush, and food creatures can likewise communicate microbes to other creature species straightforwardly or by implication through natural dispersal (Laptev et al., 2019).

Aksoy, A., El Hindi, M (2021). The antimicrobial efficiency of green seaweeds from the Mediterranean coast against some pathogenic bacteria. Journal of Advances in VetBio Science and Techniques, 6(2), 121-129. https://doi.org/10.31797/vetbio.930777
Research Article

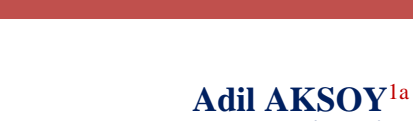

Mahmoud EL HİNDí ${ }^{2 b}$

${ }^{\mathbf{1}}$ Eskil Vocation of High

School, Laboratory

Veterinary Science, Aksaray University, Aksaray, Turkey

${ }^{2}$ Department of

Biotechnology, Faculty of Science, Islamic University of Gaza, Gaza, Palestine

ORCID-

a0000-0002-1521-3100

b0000-0002-9815-6526

Correspondence

Adil AKSOY

adilaksoy@aksaray.edu.tr

Article info

Submission: 01-05-2021

Accepted: 14-08-2021

Online First: 29-08-2021

e-ISSN: 2548-1150

doi prefix: $10.31797 /$ vetbio

- $\quad$ http://dergipark.org.tr/vetbio

This work is licensed under a Creative Commons Attribution 4.0 International License (c) $(i)$ 
Escherichia coli infections are one of the significant issues that cause an incredible danger to the productivity of poultry ranchers worldwide. The intestinal tract $E$. coli has become a normal inhabitant of poultry under the influence of predisposing factors such as inadequate and faulty ventilation, overcrowding, hunger, thirst, extremes of temperatures and low vitality, high mortality during rearing, reduced weight gain, and condemnation of birds at the time of slaughter (Elmanama et al., 2019; Khanal et al., 2019). Broiler chickens that are frequently infected with E.coli have reported depression, loss of appetite, tendency to huddle respiratory distress, reduction of weight gain, dropped wing, closed eyes, cyanosis, and labored breathing (El Seedy et al., 2019). Staphylococcus aureus (S. aureus) is a non-motile, non-spore producer, Grampositive coccus causing a wide assortment of suppurative infections in people and animals. In people, it is perhaps the most widely recognized reason for bacteremia, skin, and delicate tissue infection (Madzgalla et al., 2016; Thomer et al., 2016). While in animals, it is perhaps the most common causative specialists of clinical and subclinical mastitis in dairy ranches, causing roughly $33 \%$ of cases in steers, and bringing about huge financial misfortunes (Gussmann et al., 2019). It is a huge reason for extreme nosocomial diseases and a universally significant wellbeing concern (Benrabia et al., 2020). The chance of human pollution of poultry corpses by slaughterhouse representatives can't be precluded (Amoako et al., 2019). The natural products with biological activities from living organisms are very important for discovering new Antimicrobial agents. Such interest was expanded over the most recent very long time because of the development of pathogenic microorganisms that are impervious to significant classes of antimicrobials. Algal constituents a modest wellspring of crude materials for the extraction of different mixes of organic exercises. In addition, among all macroalgae, the green growth has a place with the variety Ulva are the least researched for antimicrobial activities when contrasted with the red (Rhodophyta) and earthy colored green growth (Phaeophyta). This work was performed to evaluate the efficacy of algae extracts $U$. clathrate, $U$. Lactuca and $U$. compressa against E. coli and S. aureus.

\section{MATERIAL and METHOD}

Algal source: The three marine Ulva species (U. clathrate, U. Lactuca and U. compressa) were that corresponded roughly to the months of June, July and August in 2016, and July and August in 2017, from uncovered rough destinations close to the edge of the shore of the Mediterranean Sea (https://goo.gl/maps/r3y4h UrfR12jkuz96). The ordered ID of species was finished by utilizing standard writing and ordered keys. The gathered green growth was moved to the research facility, where they were washed completely with tap water to eliminate any related flotsam and jetsam like sand and shells, and afterward, the drying-of examples were left in the shadow of the room temperature for fourteen days.

Preparation of algae sample: The drying process is followed by samples' cutting process into little pieces, ground to a fine powder, and put away in firmly shut plastic cups in dull at room temperature until usage.

Preparation of algae extracts: 30 grams of finely ground test powder extracted in a Soxhlet extractor by using $300 \mathrm{ml}$ of with methanol, chloroform, and hexane for 8 hours. The resulting extracts were evaporated using oven temperature $37^{\circ} \mathrm{C}$ for 3 days. Then all extracts were dissolved in DMSO. One gram of each extract was dissolved in $5 \mathrm{ml}$ of DMSO. The standard concentration of extracts was $200 \mathrm{mg} /$ $\mathrm{ml}$. Then extracts were sterilized using $0.22 \mu \mathrm{m}$ membrane filters and all samples were maintained at $-4^{\circ} \mathrm{C}$ until used (Pina-Pérez et al., 2017). 
Test Microorganisms: For the antibacterial assessment, cultures of Gram-positive bacteria $S$. aureus and Gram-negative E. coli were utilized as test microorganisms. All microorganisms provided by the Department of Biology and Biotechnology, Faculty of Science, Islamic University of Gaza, Palestine.

The antibiotic sensitivity assay: Antibiotic sensitivity test was performed by disc diffusion method. By using sterile forceps, the selected of antibiotics (Table 1.) were put on the surface of plate. The plates were incubated at $37^{\circ} \mathrm{C}$ for 24 h. Then the zones of inhibition were measured in millimeter by using ruler. (Kirbag et al, 2009; Mabrouk, 2012). Sensitivity assay was labeled sensitive, center, or protected, considering the CLSI standards. A total of 15 antimicrobials were used in this examination as exhibited in (Table 1.)

Table 1. List of antibiotic potency.

\begin{tabular}{|lccl|}
\hline Antibiotics & Symbol & Antibiotics potency & \\
\hline Cefotaxime & CXM & $30 \mathrm{mg}$ & Mimedia, Indian \& Bioanalyse, Turkey \\
\hline Cefuroxime & CTX & $30 \mathrm{mg}$ & Himedia, Indian \& Bioanalyse, Turkey \\
\hline Cefaclor & CEC, CF & $30 \mathrm{mg}$ & Himedia, Indian \& Bioanalyse, Turkey \\
\hline Cefalexin & CL, CN & $30 \mathrm{mg}$ & Himedia, Indian \& Bioanalyse, Turkey \\
\hline Ofloxacin & OFX & $5 \mathrm{mg}$ & Himedia, Indian \& Bioanalyse, Turkey \\
\hline Ciprofloxacin & CIP & $5 \mathrm{mg}$ & Himedia, Indian \& Bioanalyse, Turkey \\
\hline Norfloxacin & NOR & $10 \mathrm{mg}$ & Himedia, Indian \& Bioanalyse, Turkey \\
\hline Nalidixic acid & NA & $30 \mathrm{mg}$ & Himedia, Indian \& Bioanalyse, Turkey \\
\hline Amikacin & AK & $30 \mu \mathrm{g}$ & Himedia, Indian \& Bioanalyse, Turkey \\
\hline Gentamicin & GMN & $10 \mathrm{mg}$ & Himedia, Indian \& Bioanalyse, Turkey \\
\hline Ampicillin & AM & $10 \mathrm{mg}$ & Himedia, Indian \& Bioanalyse, Turkey \\
\hline Oxacillin & OX & $1 \mathrm{mg}$ & Himedia, Indian \& Bioanalyse, Turkey \\
\hline Amoxiclav & AMC & $30 \mathrm{mg}$ & Himedia, Indian \& Bioanalyse, Turkey \\
\hline Rifampicin & RIF & $5 \mathrm{mg}$ & Himedia, Indian \& Bioanalyse, Turkey \\
\hline Penicillin G & P & $10 \mathrm{mg}$ & Himedia, Indian \& Bioanalyse, Turkey \\
\hline Tetracycline & TE & $30 \mathrm{mg}$ & Himedia, Indian \& Bioanalyse, Turkey \\
\hline
\end{tabular}

Well-diffusion test: Antibacterial activity was examined utilizing the agar well-diffusion test. Muller Hinton Agar Medium (MHA) were disinfected via autoclaving at $121^{\circ} \mathrm{C}$ and $15 \mathrm{lbs}$. pressure for 20 minutes. Autoclaved mediums were inoculated with bacterial strain under aseptic conditions and wells (diameter $=6 \mathrm{~mm}$ ) were filled with $50 \mu \mathrm{l}$ of the test samples and incubated at $37{ }^{\circ} \mathrm{C}$ for 24 hours. After incubation, all plates were noticed for a clear zone around the well. The diameter of the growth inhibition zones was measured in millimeters. (El-Hindi et al., 2017; Sharma, 2011).

$\begin{array}{lllr}\text { Algal Extracts } & \text { Least } & \text { Inhibitory } \\ \text { Concentration } & \text { (MIC): } & \text { The } & \text { antibacterial }\end{array}$

activity of extracts against tested bacteria was also evaluated by the broth macrodilution method (96- well plates). Algal Extracts were diluted a number of times through a sterile diluent and the obtained concentration ranges were from (100 to 0.1953$) \mathrm{mg} / \mathrm{ml} .10 \mu \mathrm{l}$ of bacterial suspension $\left(10^{6} \mathrm{CFU} / \mathrm{ml}\right)$ was added to each well except a positive control. Extracts with media was used as a positive control and inoculum with media was used as a negative control. The test plates were incubated at $37^{\circ} \mathrm{C}$ for $24 \mathrm{~h}$. After $18 \mathrm{~h} 50 \mu \mathrm{l}$ of a $0.01 \%$ solution of 2, 3, 5 triphenyl tetrazolium chloride (TTC) as indicator was added to the wells and the plate was incubated for another hour. The colorless tetrazolium salt is reduced to red colored 
product by active bacteria, the inhibition of growth can be detected when the solution in the wells remains clear after incubation with TTC (Adwan, and Mhanna, 2008; Gupta and Sharma, 2006; Souza et al., 2005).

\section{RESULTS}

Antibiotics assays Measurement: The results in (Table 2.) showed the antimicrobial activity of some Antibiotics including Ciprofloxacin (CIP), Ampicillin (AM), Cefotaxime (CTX), Nalidixic destructive (NA), Norfloxacin (NOR), Cefuroxime (CXM), Cefaclor (CF or CEC), Ofloxacin (OFX), Cefalexin (CL or $\mathrm{CN}$ ), Tetracycline (TE), Rifampicin (RIF), Amoxyclav (AMC), Gentamycin (GMN), Penicillin (P) and Oxacillin (OX), while Amikacin (AK) by disc diffusion method against tested microorganisms (Table 2.).

Table 2. Impact of antibiotic reference standard on pathogenic microorganisms (hindrance zone communicated by $\mathrm{mm})$.

\begin{tabular}{|c|c|c|c|c|c|c|c|c|c|c|c|c|c|c|c|c|c|}
\hline & Antibiotics & $\frac{\Omega}{x y}$ & $\mathbb{B}$ & ? & $\mathbb{Z}$ & $\underset{Z}{Z}$ & $\frac{8}{3}$ & 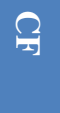 & $\underset{x}{0}$ & $\Omega$ & 是 & 备 & $\frac{\vec{z}}{2}$ & $\stackrel{\Omega}{Z}$ & $\nabla$ & $\stackrel{\ominus}{x}$ & $\mathbb{X}$ \\
\hline \multicolumn{18}{|l|}{ Bacteria } \\
\hline E. coli & & 0 & 0 & 0 & 0 & 0 & 0 & 0 & 0 & 0 & 9 & 8 & 0 & 11 & $*$ & $*$ & 20 \\
\hline S. aureus & & 0 & 0 & 0 & $*$ & 0 & 0 & 0 & 0 & 0 & $*$ & $*$ & 0 & $*$ & 7 & 0 & 22 \\
\hline
\end{tabular}

*. Not tested, mm. millimeter.

Well-diffusion test: The results in (Table 3.) showed the antimicrobial activity by well diffusion method against tested microorganisms. Methanol and chloroform extracts of $U$. clathrate, $U$. lactuca and $U$. compressa showed antibacterial action toward S. aureus and E. coli. In each case, the hexane concentrations of the three Ulva species didn't show any antibacterial action against the tested bacteria. The methanol and chloroform extracts of $U$. clathrate showed antibacterial action against all tested microorganisms and the methanol extracts showed better antibacterial action than the chloroform extracts. The information additionally indicated that are Gram-negative and Gram-positive bacteria were influenced by algal extracts. Notwithstanding, $U$. clathrate, $U$. lactuca and $U$. compres were active towards Gram-negative bacteria (E. coli) than Gram-positive bacteria (S .aureus).

Table 3. The inhibition zone in millimeter $(\mathrm{mm})$ of methanol extracts of $U$. clathrate, U. lactuca, and $U$. compressa against $E$. coli and $S$. aureus.

\begin{tabular}{|clccc|}
\multirow{2}{*}{ Bacteria } & \multicolumn{1}{c}{ Algae } & $\begin{array}{c}\text { Experiment } \\
\mathbf{1}(\mathbf{m m})\end{array}$ & $\begin{array}{c}\text { Experiment } \\
\mathbf{2}(\mathbf{m m})\end{array}$ & $\begin{array}{c}\text { Standard Deviation } \\
\pm \text { Mean }(\mathbf{m m})\end{array}$ \\
\hline \multirow{3}{*}{ E. coli } & U. clathrate & 15 & 12 & $2.1 \pm 13.5$ \\
\cline { 2 - 5 } & U. lactuca & 12 & 13 & $0.7 \pm 12.5$ \\
\cline { 2 - 5 } S. aureus & U. compressa & 13 & 11 & $1.4 \pm 12$ \\
& U. clathrata & 12 & - & - \\
\hline & U. lactuca & - & - & - \\
\hline
\end{tabular}

Methanol extract: The methanol extract of $U$. clathrate showed $13.5 \mathrm{~mm}$ zone of inhibition against E. coli and $12 \mathrm{~mm}$ against S. aureus. The Methanol extract from U. lactuca showed 12.5 zone of inhibition mm against $E$. coli. The least activity action $(12 \mathrm{~mm})$ was seen with a methanol extract of $U$. compressa and $U$. clathrate towards $E$. coli and $S$. aureus independently. No effect of the methanol extracts from $U$. lactuca and $U$. compressa against $S$. aureus. 
Chloroform extract: The chloroform extract of $U$. compressa showed of $12.5 \mathrm{~mm}$ zone of inhibition against $E$. coli and $10.5 \mathrm{~mm}$ against $S$. aureus. The chloroform extract of $U$. clathrate showed $12 \mathrm{~mm}$ zone of inhibition against $S$. aureus, and $10.5 \mathrm{~mm}$ against E. coli. The chloroform extract of $U$. lactuca showed 11 mm zone of inhibition against $E$. coli (Table 4.).

Table 4. The zone of inhibition in millimeter $(\mathrm{mm})$ of chloroform extracts of $U$. clathrate, $U$. lactuca, and $U$. compressa against E. coli and $S$. aureus.

\begin{tabular}{|c|c|c|c|c|}
\hline Bacteria & Algae & $\begin{array}{l}\text { Experiment } \\
1 \text { (mm) }\end{array}$ & $\begin{array}{l}\text { Experiment } \\
2(\mathrm{~mm})\end{array}$ & $\begin{array}{l}\text { Standard Deviation } \\
\pm \text { Mean (mm) }\end{array}$ \\
\hline \multirow{3}{*}{ E. coli } & U. clathrate & 11 & 10 & $0.7 \pm 10.5$ \\
\hline & U. lactuca & 10 & 12 & $1.4 \pm 11$ \\
\hline & U. compressa & 12 & 13 & $0.7 \pm 12.5$ \\
\hline \multirow{3}{*}{ S. aureus } & U. clathrata & 12 & 12 & $0 \pm 12$ \\
\hline & U. lactuca & - & - & - \\
\hline & U. compressa & 11 & 10 & $0.7 \pm 10.5$ \\
\hline
\end{tabular}

\section{Minimum Inhibitory Concentrations}

(MICs): MIC values of all tested fruit extracts against tested microorganisms are summarized in (Tables 5.-7.).

Methanol extract: As observed in (Table 5.), the growth of $E$. coli and $S$. aureus was inhibited by the methanolic extract of $U$. clathrate at concentrations of 3.125 and 12.5 $\mathrm{mg} / \mathrm{ml}$ separately. For the methanolic extract of $U$. lactuca, the growth of both $E$. coli and $S$. aureus was repressed at $12.5 \mathrm{mg} / \mathrm{ml}$. Methanolic extract from $U$. compressa showed antibacterial action against the two tested bacteria, and the strong activity showed against E. coli $(\mathrm{MIC}=6.25 \mathrm{mg} / \mathrm{ml})$, and against $S$. aureus $(\mathrm{MIC}=12.5 \mathrm{mg} / \mathrm{ml})$.

Table 5. The MICs (mg/ml) of methanol extract of green algae against the tested bacteria

\begin{tabular}{|lcc|}
\hline Algae & \multicolumn{2}{c|}{ Bacteria } \\
& & S. aureus \\
\hline U. clathrata & $\boldsymbol{E}$. coli & 12.5 \\
\hline U. lactuca & 3.125 & 12.5 \\
\hline U. compressa & 12.5 & 12.5 \\
\hline
\end{tabular}

Table 6. The MICs $(\mathrm{mg} / \mathrm{ml})$ of chloroform extract of green algae against the tested bacteria

\begin{tabular}{|lcc|}
\hline Algae & \multicolumn{2}{c|}{ Bacteria } \\
\hline U. clathrata & E. coli & 25 \\
\hline U. lactuca & 25 & 25 \\
\hline U. compressa & 12.5 & 100 \\
\hline
\end{tabular}

Chloroform extract: As observed in (Table 6.), the MIC of the chloroform extract of $U$. clathrate for E. coli and for $S$. aureus was 25 $\mathrm{mg} / \mathrm{ml}$. The MIC of chloroform extract of $U$. lactuca against $E$. coli was $12.5 \mathrm{mg} / \mathrm{ml}$ and was $25 \mathrm{mg} / \mathrm{ml}$ for $S$. aureus. The growth of $E$. coli was inhibited by the chloroform extracts 12.5 $\mathrm{mg} / \mathrm{ml}$, and $100 \mathrm{mg} / \mathrm{ml}$ for $S$. aureus. 
Table 7. The MICs $(\mathrm{mg} / \mathrm{ml})$ of hexane extract of green algae against the tested bacteria.

\begin{tabular}{|lcc|}
\hline Algae & Bacteria & S. aureus \\
\hline U. clathrata & E. coli & 25 \\
\hline U. lactuca & 25 & 25 \\
\hline U. compressa & 25 & 25 \\
\hline
\end{tabular}

Hexane extract: As observed in (Table 6.), the MIC of the chloroform extract of $U$. clathrate for $E$. coli and $S$. aureus was $25 \mathrm{mg} / \mathrm{ml}$. The MIC of chloroform extract of $U$. lactuca against E. coli was $12.5 \mathrm{mg} / \mathrm{ml}$ and was $25 \mathrm{mg} / \mathrm{ml}$ for $S$. aureus. The growth of E. coli was inhibited by the chloroform extract of $U$. compressa at 12.5 $\mathrm{mg} / \mathrm{ml}$, and $100 \mathrm{mg} / \mathrm{ml}$ for $S$. aureus.

\section{DISCUSSION}

The seaweeds (U. clathrate, U. lactuca and $U$. compressa) were separated by three solvents and assessed for their antibacterial activity against the two clinically pathogenic bacterial species of $S$. aureus and E. coli. The action of each algal concentration was assessed by two methods: well-diffusion method and lowest minimum inhibitory concentration (MIC). This study shows clearly that the green, marine seaweeds contain antibacterial compounds. They can be considered as a promising source for bioactive compounds including antibacterial agents. The outcomes here are in concurrence with the other report performed by Elnabris (Elnabris et al., 2013), which introduced the antimicrobial properties of the methanolic concentrations of marine ocean growth $U$. lactuca, U. compressa (Chlorophyta), Padina Pavonica (Phaeophyta), and Jania Rubens (Rhodophyta). The natural activity of Green Seaweeds was ascribed to the presence of Sulfated Polysaccharide (SP) of uncommon substance arrangement and construction in the cell mass of these green Seaweeds called Ulvan. Recently, Ulvan has been broadly assessed for advancing other medications and practical food sources (Wijesekara et al., 2011). Studies proposed that sulfated polysaccharides can likewise display useful bioactivity mixes such as anticoagulant, antiviral, cancer prevention agent, calming (Costa et al., 2010), and antiproliferative (Mohamed et al., 2012). The outcomes demonstrate that the methanolic concentrations of all Seaweeds showed preferable antibacterial activity over chloroform and hexane extracts. Antimicrobial activity relies upon both algal species and the effectiveness of the extraction. A couple of assessments concerning the suitability of extraction procedures include that the methanol extraction yields higher antibacterial activity than various solvents such as hexane and chloroform (Sastry and Rao, 1994; Seenivasan et. al, 2010) and likewise propose that methanol is the best for separating the successful antibacterial materials from the green algae species. Other studies reported that chloroform is superior to methanol (Omar et al., 2012; Rajasulochana et al., 2009) and found that the petrol ether, diethyl, and ethyl acetic acid derivation were better than methanol for extracting the bioactive compounds from green algae. The algal extracts of $U$. clathrate have higher antibacterial activities against the tested bacteria than extracts of $U$. lactuca and $U$. compressa which may indicate that $U$. clathrate has good antibacterial activity-related compounds. Methanolic separates $U$. clathrate exhibited more noteworthy cell reinforcement potential and the most elevated phenolic substance and flavonoid content in correlation with those of different types of green kelp from Northern Coasts of the Persian Gulf (Farasat et al., 2014). Sulfated polysaccharides Ulvan from $U$. clathrate was found to have antiviral action 
and repress viral connection/section and cellcell combination in NDV contamination (Aguilar-Briseño et al., 2015). Furthermore, the new examination has another huge outcome which was the moderate antibacterial movement of the concentrations of $U$. lactuca when tried against the E. coli and S. aureus development. No antimicrobial action was additionally announced by (Perez et al., 1990) when the natural concentrations of similar green seaweeds were assessed. Variety in effects of these investigations might be because of species variety, the time (season) and area of test assortment, and the amount of test utilized (Sivakumar, and Vignesh, 2014). In the present study, the well-diffusion and MIC method using 2,3,5,-triphenyl tetrazolium chloride (TTC) as an indicator was used as biological assays to evaluate the antibacterial activities of seaweeds because of their technical simplicity, effectiveness, sensitivity, rapidity, and relatively low cost of these methods. Additionally, if the color intensity of the red formazan formed in the microdilution method is measured using a spectrophotometer at $480 \mathrm{~nm}$, the test could also provide a quantitative determination of the antibacterial activity of antibacterial agents (Moussa et al., 2013). Seaweeds were evaluated and exhibited higher antimicrobial activity towards Gram-negative bacteria than the Gram-positive bacterial species. E. coli was noted to have larger inhibition diameters and nearly have fewer MICs than S. aureus. Similarly, Seenivasan et al., (2010) reported a more inhibitive effect of Acetone, Methanol, and Ethanol extracts of three marine green algae species (Chaetomorpha aerea, Enteromorpha intestinalis, Ulva fasciata) on the growth of Gram-negative bacteria such as E. coli, than Gram-positive bacteria such as $S$. aureus. This is intriguing since a few reports concerning the antimicrobial action of kelp indicated opposite outcomes (Ibtissam et al., 2009; Taskin et al., 2010). A few researchers propose that the Gram-negative bacteria have an external layer act as a boundary to numerous natural substances, including antimicrobials (Tortora et al., 2001; Tshikalange et al., 2005). The perceptions of the current investigation show that the connections between the measurements of the restraint zones and the MIC esteems differed and may rely upon the sort of dissolvable utilized and the bioactive compounds included (Cox et al, 2010). Hexane separates didn't show any antimicrobial action against the tried microbes in the well-diffusion method. This outcome could be likely due to the non-polar nature of the compound extracted by hexane which couldn't diffuse well in the agar polar climate. Comparatively opposed to the well-diffusion method, all algae seaweed showed antimicrobial action against microorganisms in the microdilution technique.

\section{CONCLUSION}

In conclusion, the results demonstrated that the crude extract of green seaweeds under investigation exhibited antimicrobial activities against the tested bacteria species. This proved that the marine macroalgae are potential sources of biologically active compounds which are effective in resisting bacterial growth and could be investigated for Antimicrobial agents invention for many drug-resistance microorganisms. Marine algae are also gaining growing prominence in the pharmaceutical industries around the world. Further biochemical analyses, however, are necessary to isolate, characterize, and determine the bioactivity compounds. Overall, the present study provides data to show the potential utilization of green growth extracts for the advancement against microbial specialists for treating irresistible illnesses. 


\section{ACKNOWLEDGMENT}

Ethical approval: This article doesn't contain any examinations with animal members or creatures performed by any of the writers.

Conflict of interest: The authors declared that there is no conflict of interest.

\section{KAYNAKLAR}

Adwan, G., \& Mhanna, M. (2009). Synergistic effects of plant extracts and antibiotics on Staphylococcus aureus strains isolated from clinical specimens. Asian Pacific Journal of Tropical Medicine, 2(3), 46-51.

Aguilar-Briseño, JA., Cruz-Suarez, L, E., Sassi, J, F., Ricque-Marie, D., Zapata-Benavides, P., MendozaGamboa, E., Rodríguez-Padilla, C., Trejo-Avila, LM. (2015). Sulfated polysaccharides from Ulva clathrate and Cladosiphon okamuranus seaweeds both inhibit viral attachment/entry and cell-cell fusion. in NDV infection. Marine drugs, 13(2), 697712.

Amoako, D, G., Somboro, A, M., Abia, A, L, K., Allam, M., Ismail, A., Bester, L., \& Essack SY. (2019). Genomic analysis of methicillin-resistant Staphylococcus aureus isolated from poultry and occupational farmworkers in Umgungundlovu District. South Africa. Science of the total environment, 670, 704-716.

Benrabia, I.., Hamdi, T, M., Shehata, A, A., Neubauer, H., \& Wareth, G. (2020). MethicillinResistant Staphylococcus aureus (MRSA) in Poultry Species in Algeria: Long-Term Study on Prevalence and Antimicrobial Resistance. Veterinary Sciences, $7(2), 54$.

Chiheb, I., Riadi, H., José, M, L., Francisco, D, S, J., Antonio, G, V, J., Bouziane, H., and Kadiri, M. (2009). Screening of antibacterial activity in marine green and brown macroalgae from the coast of Morocco. African Journal of Biotechnology, 8(7), 1258-1262.

CLSI Performance standards for antimicrobial susceptibility testing. Approved Standards CLSI. 2010: M100-S20.

Costa, L, S., Fidelis, G, P., Cordeiro, S, L., Oliveira, R, M., Sabry, D, D, A., Câmara, R, B, G., Costa, M, S, S, P., Almeida-Lima, J., Farias, E, H, C., Leite, E, L., Rocha, H, A, O. (2010). Biological activities of sulfated polysaccharides from tropical seaweeds. Biomedicine \& Pharmacotherapy, 64(1), 21-28.

Cox, S., Abu-Ghannam, N., Gupta, S. (2010). An assessment of the antioxidant and antimicrobial activity of six species of ddible Irish seaweeds. International Food Research Journal, 17, 205-220.

Das, A, K., Niang, H., Sahoo, A, K., Kumar, S., \& Das D. (2019). Retrospect of breeding for genetic resistance to diseases in poultry and farm animals. Indian Journal of Animal Health, 58(1), 21-44.
El Seedy, F, R., Abed, A, H., Wafaa, M, M, H., Bosila, A, S., \& Mwafy, A. (2019). Antimicrobial resistance and molecular characterization of pathogenic $E$. coli isolated from chickens. Journal of Veterinary Medical Research, 26(2), 280-292.

El-Hindi, M., Mosleh, F., Aldine, S., Gharbiya, R., ElKichaoui, A. (2017). Antibacterial potentiality of water extract of selected honey samples on some clinical isolates. The Pharmaceutical and Chemical Journal, 4(3), 37-42.

Elmanama, A, A., Al-Reefi, M, R., Shamali, M, A., \& Hemaid, H, I. (2019). Carbapenems Resistance among Gram-Negative Bacteria Isolated from Poultry Samples in Gaza-Palestine. The International Arabic Journal of Antimicrobial Agents, 8, (3).

Elnabris, K, J., Elmanama, A, A., \& Chihadeh, W, N. (2013). Antibacterial activity of four marine seaweeds collected from the coast of Gaza Strip, Palestine. Mesopotamian Journal of Marine Science, 28(1), 8192.

Farasat, M., Khavari-Nejad, R, A., Nabavi, S, M, B., \& Namjooyan, F. (2014). Antioxidant activity, total phenolics and flavonoid contents of some edible green seaweeds from northern coasts of the Persian Gulf. Iranian Journal of pharmaceutical research, 13(1), 163.

Gupta, V, K., \& Sharma, S, K. (2006). Plants as natural antioxidants. Natural product radiance, 5(4), 326334.

Gussmann, M., Steeneveld, W., Kirkeby, C., Hogeveen, H., Farre, M., Halasa, T. (2019). Economic and epidemiological impact of different intervention strategies for subclinical and clinical mastitis. Preventive veterinary medicine, 166, 78-85.

Khanal, S., Kandel, M., \& Shah, M. P. (2019). Antibiogram pattern of Escherichia coli, Salmonella spp. and Staphylococcus spp. isolates from broiler chicken. Nepalese Veterinary Journal, 36, 105-110.

Kirbag, S., Zengin, F., Kursat, M. (2009). Antimicrobial activities of extracts of some plants. Pakistan Journal of Botany, 41(4), 2067-2070.

Laptev, G, Y., Filippova, V, A., Kochish, I, I., Yildirim, E, A., Ilina, L, A., Dubrovin, A,V., Brazhnik, E, A., Novikova, N, I., Novikova, O, B., Dmitrieva, M, E., Smolensky, V, I., Surai, P, F., Griffin, D, K., Romanov, M, N. (2019). Examination of the expression of immunity genes and bacterial profiles in the caecum of growing chickens infected with Salmonella enteritidis and fed a phytobiotic. Animals, 9(9), 615.

Logue, C, M., Andreasen, C, B., Borst, L, B., Eriksson, H., Hampson, D, J., Sanchez, S., Fulton R, M. (2020). Other Bacterial Diseases. In D.E. Swayne, M. Boulianne, C.M. Logue, L.R. McDougald, V. Nair, D.L. Suarez, S. Wit, T. Grimes, D. Johnson, M. Kromm, T.Y. Prajitno, I. Rubinoff and G. Zavala (Eds.), Diseases of Poultry (pp.9951085). https://doi.org/10.1002/9781119371199.ch23

Mabrouk, M, I. (2012). Synergistic and antibacterial activity of six medicinal plants used in folklore medicine in Egypt against E. coli O157. H7. Journal of Application Science Research, 8(2), 1321-1327. 
Madzgalla, S., Syed, M, A., Khan, M, A., Rehman, S, S., Muller, E., Reissig, A., Ehricht, R., Monecke, S. (2016). Molecular characterization of Staphylococcus aureus isolates causing skin and soft tissue infections in patients from Malakand, Pakistan. European Journal of Clinical Microbiology \& Infectious Diseases, 35, 1541-1547.

MOHAMED, S., HASHIM, S, N., RAHMAN, H, Abdul. (2012). Seaweeds A sustainable functional food for complementary and alternative therapy. Trends in Food Science \& Technology, 23(2), 83-96.

Moussa, S, H., Tayel, A, A., Al-Hassan, A, A., \& Farouk, A. (2013). Tetrazolium/Formazan test as an efficient method to determine fungal chitosan antimicrobial activity. Journal of Mycology, Volume 2013, Article ID 753692, 7 pages. http://dx.doi.org/10.1155/2013/753692

Omar, H, H., Shiekh, H, M., Gumgumjee, N, M., ElKazan, M, M., El-Gendy, A, M. (2012). Antibacterial activity of extracts of marine algae from the Red Sea of Jeddah, Saudi Arabia. African Journal of Biotechnology, 11(71), 13576-13585.

Perez, R, M., Avila, A, J, G., Perez, G, S., Martinez, C, A., Martinez, C, G. (1990). Antimicrobial activity of some American algae. Journal of Ethnopharmacology, 29, 111-18.

Pina-Pérez, M, C., Rivas, A., Martínez. A., Rodrigo, D. (2017). Antimicrobial potential of macro and microalgae against pathogenic and spoilage microorganisms in food. Food Chemistry, 235, 34-44.

Rajasulochana, P., Dhamotharan, R., Krishnamoorthy, P., \& Murugesan, S. (2009). Antibacterial activity of the extracts of marine red and brown algae. The Journal of American Science, 5(3), 20-25.

Sastry, V, M, V, S., Rao, G, R, K. (1994). Antibacterial substances from marine algae: successive extraction using benzene, chloroform, and methanol. Botanica Marina, 37, 357-360.

Seenivasan, R., Indu, H., Archana, G., \& Geetha, S. (2010). The Antibacterial activity of some marine algae from the southeast coast of India. Journal of Pharmacy Research, 3(8), 1907-1912.

Sharma, A. (2011). Antibacterial activity of ethanolic extracts of some arid zone plants. International Journal of PharmTech Research, 3, 283-286.

Sivakumar. S. R., and Vignesh, A. (2014). In vitro activity of seaweed extracts collected from Gulf of Mannar coast islands Tamilnadu on clinical isolates. World Journal of Fish and Marine Sciences, 6(6), 504-508.

Souza, S, M., Delle-Monache, F., Smânia, A. (2005). Antibacterial activity of coumarins. Zeitschrift für Naturforschung C, 60(9-10), 693-700.

Taskin, E., Caki, Z., Ozturk, M., Taskin, E. (2010). Assessment of in vitro antitumoral and antimicrobial activities of marine algae harvested from the eastern Mediterranean Sea. African Journal of Biotechnology. 9(27), 4272-4277.

Thomer, L., Schneewind, O., Missiakas, D. (2016). Pathogenesis of Staphylococcus aureus bloodstream infections. Annual Review of Pathology: Mechanisms of Disease, 11, 343-364.
Tortora, G, J., Funke, B, R., Case, C, L. (2001). In Microbiology. An Introduction. Benjamin Cummings, San Francisco.; 88 pp.

Tshikalange, T, E., Meyer, J, J, M., Hussein, A. A. (2005). Antimicrobial activity, toxicity, and the isolation of a bioactive compound from plants used to treat sexually transmitted diseases. Journal of Ethnopharmacology, 96, 515-519.

Wijesekara, I., Pangestuti, R., Kim, S, K. (2011). Biological activities and potential health benefits of sulfated polysaccharides derived from marine algae. Carbohydrate polymers, 84(1), 14-21. 